\title{
Mhcj

\section{Territorios Fotográficos. Entre el camino de la acción y el espacio de participación}

\section{Photographic Territories. Between the path of action and the space of participation}

Elpidio del Campo Cañizares | edelcampo@umh.es

Universidad Miguel Hernández

Leónidas Spinelli Capel | 1spinelli@umh.es

Universidad Miguel Hernández

Actualmente la fotografía se encuentra en un proceso de reformulación constante que viene dado tanto por la acción que representa como por los espacios de participación donde se produce. Un proceso que incide directamente en la concepción del medio, en un ir y venir constante entre los aspectos clásicos de la imagen y la continua transformación de los entornos digitales.

En su práctica artística contemporánea, la fotografía traspasa constantemente sus propias fronteras interactuando con otras disciplinas y desafiando la conceptualización de lo fotográfico. Ya no es posible la aproximación inocente al medio, la postfotografía ha dinamitado aún más sus límites para exigir una perpetua reflexión sobre el hecho fotográfico.

Este proceso expansivo abre innumerables posibilidades y, al mismo tiempo, muestra la mutabilidad y adaptabilidad del medio. Asimismo, su exponencial multiplicación en la sociedad digital demanda acercamientos rigurosos desde lo social y profesional. Este análisis es hoy indispensable para entender los procesos comunicativos, los mecanismos de construcción y cohesión social y los incesantes cambios en las percepciones fotográficas. Los límites difusos de la acción fotográfica hacen imprescindible la reflexión desde una mirada multidisciplinar que proponga una nueva cultura fotográfica. 
Las plataformas que potencian la reflexión fotográfica construyen redes de conocimiento y colaboración que ayudan a difundir los avances en las esferas creativa, profesional y de investigación. Así, uno de los principales objetivos de este monográfico es apoyar de forma explícita la discusión y el debate acerca de los diferentes estados en los que la fotografía se encuentra y ofrecer claves para su futuro, sin olvidar su rico legado.

Así pues, este monográfico recoge un compendio de trabajos con múltiples y variadas perspectivas que sirven para ofrecer rutas por las que rastrear los caminos de la fotografía. En sintonía con la voluntad ecléctica que nos animaba, los estudios que se proponen a continuación abarcan funciones artísticas, creativas, periodísticas y documentales de la fotografía para ofrecer un múltiple abanico de miradas.

Alicia Parras y Julia R. Cela presentan bajo el título Una mirada documental de la fotografía underground a través del fanzine Rockocó. Análisis del Archivo Miguel Trillo en el Museo Nacional Centro de Arte Reina Sofía (MNCARS), un análisis documental que sigue las indicaciones teóricas de Salvador Benítez, Olivera Zaldua y Sánchez Vigil sobre el fanzine Rockocó creado por Miguel Trillo entre 1980 y 1984. Las conclusiones más relevantes corroboran el papel fundamental de Miguel Trillo como documentalista de las tribus urbanas en el Madrid de los 80; pero también cómo su legado ha sido recogido por fotógrafos contemporáneos y es claramente perceptible en los trabajos de Laura C. Vela y Davit Ruiz.

Beatriz Guerrero, en La fotografía documental y la utopía, se centra en debatir sobre lo que se entiende por fotografía documental y cuáles son las características debe tener una imagen para ser considerada documental. Posteriormente, retomando los orígenes de la tradición documentalista a principios del siglo XX en EEUU (con su fuerte voluntad de transformación y mejora de las capas más desfavorecidas de la sociedad), expone el ejemplo de los recientes proyectos de Ana Palacios estrechamente ligados al trabajo con las ONGs en los países del África subsahariana y Asia. De este modo, la autora afirma que la fotografía documental actual no renuncia a la utopía transformadora y de progreso social que tuvo en sus orígenes.

Sandra Martorell y Álvaro Sanchís presentan los resultados de su análisis La fotografía artística contemporánea en el marco de la promoción cultural. Los carteles del Centro Dramático Nacional como caso de estudio. Este trabajo pone de manifiesto el papel clave de la fotografía en las corrientes contemporáneas de diseño gráfico. Mediante un estudio cualitativo basado en entrevistas y el análisis formal de los carteles del CDN se expone la voluntad de crear sinergias con otras disciplinas artísticas para generar la fuerte identidad visual actual del CDN. Si bien en este caso la fotografía está al servicio del concepto creativo de los diseñadores, se revela como 
herramienta fundamental para artistas como Javier Jaén, Isidro Ferrer y Cecilia Molano.

Juan Carlos Gómez y Andrés Ballesteros, en Contenidos gráficos generados por fotógrafos ciudadanos y publicados por los medios. El caso del fotógrafo Jacobo Méndez. Díez en El País, analizan el creciente papel que juegan los ciudadanos como generadores de contenido para los medios de comunicación. El periodismo ciudadano, directamente vinculado a la web 2.0, supone un reto para los medios tradicionales; pero también una oportunidad para ampliar sus registros y conectar con nuevas audiencias. El caso de la fotografía del aficionado Jacobo Méndez Díez publicada en portada en El País (21/05/2011) con motivo de las movilizaciones de mayo de 2011 en España (y premiada con el Ortega y Gasset gráfico al año siguiente), representa el mejor ejemplo de cómo puede ser fructífera la colaboración entre los medios y los ciudadanos que producen su propia información.

En el mismo ámbito de estudio, Nereida Cea presenta La fotografía periodística y los social media: la jornada del 1 de octubre en Cataluña y analiza el papel que está jugando la fotografía en el contexto de interacción entre las redes sociales y el periodismo profesional. Se observa que cada vez es más frecuente en los cibermedios la fotografía procedente de los social media; pero esto trae consigo el problema fundamental de la verificación de los contenidos al que los medios deben hacer frente. El acelerado ritmo del flujo comunicativo de las redes colisiona con los tiempos necesarios para los procesos de verificación. A partir del estudio de la cobertura informativa de la jornada del 1 de octubre de 2017 en Barcelona, se describe el creciente peligro al que se exponen los medios para no caer en la difusión de fake news.

Víctor Lope titula su trabajo Estética e ideología en las secuencias de créditos de las series El puente y Mindhunter. Ambas series de TV —Bron/Broen (2011, SVT 1) y Mindhunter (2017, Netflix) - forman parte de una nueva cultura con audiencias cada vez mayores (en ocasiones masivas) a través de canales de VOD; pero también sirven de vanguardia y experimentación audiovisual para los creadores más inquietos. Su análisis de las secuencias de los créditos de estas series explora la relación entre la estética que presentan y la ideología que proponen; concluyendo que en ambas hay una estetización de la oscuridad, la falta de horizonte y el sinsentido. La mayor proclama ideológica en ambas es una relativización de los significantes haciendo ver que no hay referentes para la verdad salvo el horror, considerado este como la única certeza.

Elena Torelishvili presenta el artículo Tradiciones e innovaciones del uso del cinematógrafo en la escenografía teatral en el ballet Oda de Pável Tchelitchew. En él hace un exhaustivo recorrido histórico por las obras clave y los artistas que marcaron la introducción de las tecnologías de la iluminación y proyección cinematográfica en la escenografía a principios del siglo XX; 
especialmente vinculados a la danza moderna y los Ballets Rusos de Serguéi Diáguilev. En este contexto creativo, el trabajo escenográfico de Tchelitchew para el ballet Oda supuso un hito y la culminación de la experimentación de las vanguardias. Mediante los testimonios de artistas coetáneos y amigos de Tchelichew y las reseñas críticas publicadas en los periódicos de la época, la autora reconstruye el impacto que causó el estreno de aquella obra en su tiempo.

Naia del Castillo, en su texto Relaciones entre escultura, fotografía y acción en la práctica artística propia, lleva a cabo una revisión de su práctica artística inscrita en la escena contemporánea. El trabajo presentado es un análisis de la obra realizada entre los años 2000 y 2017 que hibrida el performance, la fotografía y la escultura en las series Atrapados, Sobre la seducción, Ofrendas y Posesiones, Desplazamientos, Flujos e Hilos y Trazos. Se entretejen conceptos aparentemente opuestos como la apariencia y la presencia, el instante, la duración y la atemporalidad, junto con usos del fetiche y del doble conceptual. Todo ello plantea su reflexión acerca de la realidad, no para representarla sino para darle una réplica.

Creemos que el conjunto de textos recogidos en este monográfico es el mejor ejemplo de la capacidad de la fotografía para reinventar continuamente sus significados y usos. Por otra parte, no hay que olvidar que en la rica historia de la fotografía están las raíces que nutren sus aplicaciones más contemporáneas y complejas. Los conceptos de verdad, huella, memoria, representación... están ligados íntimamente a la fotografía; pero, de modo inevitable, continuamente se someten a relecturas y nuevas miradas que vuelven a cuestionar una y otra vez las capacidades de la fotografía para generar significados. Finalmente, con esta pequeña aportación esperamos haber contribuido a continuar el imprescindible debate sobre la esencia del hecho fotográfico. 


\section{(c) ()}

Licencia Creative Commons

Miguel Hernández Communication Journal

mhcj.es

\section{Cómo citar este texto:}

del Campo, E. y Spinelli, L. (2018): “Territorios Fotográficos. Entre el camino de la acción y el espacio de participación”, en Miguel Hernández Communication Journal, 9 (2), páginas 263 a 267 Universidad Miguel Hernández, UMH (Elche-Alicante). Recuperado el _ de de 20_ de: [link del artículo en mhjournal.org]. DOI: http://dx.doi.org/10.21134/mhcj.v0i9.273

\section{How to cite this text:}

del Campo, E. y Spinelli, L. (2018): Photographic Territories. Between the path of action and the space of participation, in Miguel Hernández Communication Journal, 9 (2), pp. 263 a 267 Universidad Miguel Hernández, UMH (Elche-Alicante). Recuperado el _ de de 20_ de: [link del artículo en mhjournal.org]. DOI: http://dx.doi.org/10.21134/mhcj.v0i9.273 